\title{
Anti-leukemia activity of semi-synthetic phenolic derivatives from Polygonum limbatum Meisn.
}

\author{
Antoine Honoré Lonfouo Nkuété1,2,3, Victor Kuete ${ }^{4,6}$, Davide Gozzini ${ }^{3}$, Ludovico Migliolo ${ }^{2,7}$, Aline Lima Oliveira ${ }^{5}$,
} Hippolyte K Wabo ${ }^{1}$, Pierre Tane ${ }^{1}$, Giovanni Vidari ${ }^{3}$, Thomas Efferth ${ }^{6 *}$ and Octávio Luiz Franco ${ }^{2,7^{*}}$

\begin{abstract}
Background: The present report describes the semi-synthesis of a few O-prenylated phenolic derivatives and their in vitro antitumor activities. These compounds were prepared by modifying two naturally occurring antitumor phenols, 5,7-dihydroxy-3-(1'-hydroxy-1'-phenyl-methyl)-6-methoxy-chroman-4-one (A) and 2',4'-dihydroxy3',6'-dimethoxychalcone (B), previously isolated from Polygonum limbatum Meisn. (Polygonaceae). The structures were elucidated by spectroscopic means and comparison with published data. The cytotoxicity of compounds was determined by using the resazurin assay in the parental drug-sensitive CCRF-CEM cell line and its multidrug-resistant P-glycoprotein-over-expressing subline, CEM/ADR5000.

Results: We describe in the present paper four new semi-synthetic derivatives of $\mathrm{A}$ and $\mathrm{B}:$ 5-hydroxy-6-methoxy-7-O(3'-methylbut-2'-enyl)chroman-4-one (1), trivially named metapchromone, 5-acetoxy-6-methoxy-7-0-[3'-methylbut-2' enyl]chroman-4-one (2), trivially named sargisin, 2'-hydroxy-3',6'-dimethoxy-4'-O-(3"-methylbut-2"-enyl)chalcone (3) trivially named limbachalcone $A$, and 2'-acetoxy-3',6'-dimethoxy-4'-O-(3"-methylbut-2"-enyl)chalcone (4) trivially named tsedengchalcone. Their preliminary cytotoxic activities have been determined. We also report herein the isolation of 1-methylhydantoin (C) and betulinic acid (D) from Polygonum limbatum for the first time.

Conclusions: The study clearly suggests that semi-synthesis involving O-prenylation and acetylation of chalcones or other chromanones should be avoided in a search for anticancer drugs. This conclusion should be helpful when selecting substituents for the synthesis of potential anticancer drugs.
\end{abstract}

Keywords: Phenolic compounds, Sargisin, Metapchromone, LimbachalconeA, Tsedengchalcone

\section{Background}

The genus Polygonum belongs to the family Polygonaceae, comprising 300 species growing all over the world, although most of them are found in temperate and tropical regions [1, 2]. Polygonum limbatum Meisn. (Polygonaceae) commonly known as "nzùnh metap" in the Western Region of Cameroon, is a perennial herb that grows widely in marshy and aquatic areas, near riverbanks [2]. In connection with our ongoing search for bioactive compounds, the phytochemical re-examination of Polygonum limbatum Meisn. allowed us to isolate 1-methylhydantoin (C), 5,7-dihydroxy-3-(1'-hydroxy-

\footnotetext{
* Correspondence: efferth@uni-mainz.de; ocfranco@gmail.com ${ }^{6}$ Department of Biochemistry, Faculty of Science, University of Dschang, Dschang, Cameroon

${ }^{2}$ Centro de Analises Proteômicas e Bioquimicas, Pós-Graduação em Ciencias Genomicas e Biotecnologia, Universidade Catolica de Brasilia, Brasilia, DF, Brazil Full list of author information is available at the end of the article
}

1'-phenyl-methyl)-6-methoxy-chroman-4-one (A), 2',4' dihydroxy-3' , $^{\prime}$-dimethoxychalcone (B), betulinic acid (D) and sitosterol 3-O- $\beta$-D-glucopyranoside (E). Compounds $\mathbf{A}$ and $\mathbf{B}$ were previously identified as antitumor phenolic compounds [3, 4]. In addition, in the present paper we describe four new semi-synthetic derivatives of compounds A and B: 5-hydroxy-6-methoxy-7-O-(3'-methylbut-2'enyl)chroman-4-one (1) trivially named metapchromone, 5-acetoxy-6-methoxy-7-O-[3'-methylbut-2'enyl] chroman4-one (2) trivially named sargisin, 2'-hydroxy-3',6'dimethoxy-4'-O-(3"-methylbut-2"-enyl)chalcone (3) trivially named limbachalcone $\mathrm{A}$, and $2^{\prime}$-acetoxy-3', 6'-dimethoxy-4'-O-(3"'-methylbut-2"'-enyl)chalcone (4), trivially named tsedengchalcone. Their preliminary antitumor activities have been determined. We also report herein the isolation of 1-methylhydantoin $(\mathbf{C})$ as a natural product from the Polygonum genus for the first time. 
The isolation of 1-methylhydantoin and betulinic acid from the Polygonum genus and the Polygonaceae family could be an important chemotaxonomic finding.

\section{Results}

The structures of natural compounds $\mathbf{A}, \mathbf{B}$ and $\mathbf{C}$ isolated from $P$. limbatum were elucidated on the basis of spectroscopic data such as IR, 1D and 2D NMR spectra. Comparison of the data with those reported in the literature led to the identification of compounds such as betulinic acid (D) [5] and sitosterol 3-O- $\beta$-D-glucopyranoside (E) [6].

The structures of the semi-synthetic derivatives, 5hydroxy-6-methoxy-7-O-(3'-methylbut-2' - enyl)chroman4-one (1), 5-acetyl-6-methoxy-7-O-(3'-methylbut-2'-enyl)chroman-4-one (2), 2'-hydroxy-3',6'-dimethoxy-4'-O-(3"methylbut-2" -enyl)chalcone (3), 2' -acetyl-3',6'-dimethoxy4'-O-(3"-methylbut-2" -enyl)chalcone (4) (Fig. 1) were determined on the basis of ${ }^{1} \mathrm{H}$ NMR, ${ }^{13} \mathrm{C}$ NMR and EIMS data and comparison with those of 5,7-dihydroxy-3(1'-hydroxy-1'-phenyl-methyl)-6-methoxy-chroman-4-one (A), 2',4'-dihydroxy-3',6'-dimethoxychalcone (B), respectively. This is the first report concerning the isolation of 1-methylhydantoin (C) from P. limbatum as well as the semi-synthesis of prenylated and acetylated derivatives from compounds $\mathbf{A}$ and $\mathbf{B}$.

Compound $\mathbf{C}$ was obtained as brownish needles from $n$-hexane-EtOAc, mp $155-157{ }^{\circ} \mathrm{C}$. It reacted negatively to the $\mathrm{FeCl}_{3}$, suggesting the absence of a phenolic group in the molecule. Its molecular formula of $\mathrm{C}_{4} \mathrm{H}_{6} \mathrm{~N}_{2} \mathrm{O}_{2}$, corresponding to 3 degrees of unsaturation, was determined by EI-MS $\left(\mathrm{M}^{+} \mathrm{m} / z\right.$ 114) in conjunction with the NMR spectra. In the ${ }^{13} \mathrm{C}$ NMR spectrum, signals at $\delta_{\mathrm{C}}$ 173.8 (C-4) and 159.9 (C-2) for two carbonyl groups, one methylene signal at $\delta_{\mathrm{C}} 29.2(\mathrm{C}-5)$ and one methyl at $\delta_{\mathrm{C}}$ $53.9\left(\mathrm{~N}-\mathrm{CH}_{3}\right)$, were characteristic of 1-methylhydantoin structure [7]. In the ${ }^{1} \mathrm{H}$ NMR spectrum, two singlets were observed at $\delta_{\mathrm{H}} 3.95$ and 2.90 , respectively, assignable to these methyl and methylene groups, respectively (Table 1). In the HMBC spectrum, pertinent correlations were observed between $\mathrm{H}-5$ and $\mathrm{C}-2, \mathrm{CH}_{3}$ and $\mathrm{C}-2$ and $\mathrm{C}-4$. The structure of compound $\mathbf{C}$ was established as 1-methyldiazolidine-2,4-dione (Fig. 2). It is a natural product from the Polygonum genus and has been fully characterized here for the first time. It has been previously reported as a synthetic compound and was found to be a renal metabolite of dupracetam [7].

Compounds $\mathbf{A}$ and $\mathbf{B}$ were prenylated under standard basic conditions by exposure to prenyl bromide. As expected, the poorly reactive chelated phenolic groups were not alkylated. In fact, subsequent acetylation of these groups required forcing conditions with the aid of 4-dimethylaminopyridine (DMAP) in a catalytic amount.

Interestingly, the prenylation of chroman-4-one A resulted in decomposition of the molecule with loss of benzaldehyde and formation of a 3-unsubstituted chromanone, namely compound $\mathbf{1}$. This rearrangement was likely due to a retro-aldol-like reaction following the mechanism shown in Fig. 3.

\section{Discussion}

In this study, we determined the cytotoxicity of the natural compound $\mathbf{A}$ as well as the semi-synthetic compounds 1-4. We previously reported the cytotoxicity of compound $\mathbf{B}[3,4]$, and the data were also reported herein for a better understanding of the structure-activity relationship (SAR). As shown in Fig. 4, the two natural compounds $\mathbf{A}$ and $\mathbf{B}$ were much more active than the semi-synthetic ones, inducing less than $20 \%$ growth of CCRF-CEM leukaemia cells. This was confirmed in the dose-response assays, as $\mathrm{IC}_{50}$ values below $20 \mu \mathrm{M}$ were recorded for the two natural compounds. Among the synthetic compounds (Table 2), 3 displayed the highest activity with $\mathrm{IC}_{50}$ values below $20 \mu \mathrm{M}$ on the two tested leukaemia cell lines. Interestingly, the resistant cell line was more sensitive to compound $\mathbf{3}$ as well as to $\mathbf{A}$ and $\mathbf{B}$ than to doxorubicin. Nonetheless, the cytotoxicity can be considered moderate [8]. In contrast to doxorubicin, which was about 1000 times less active in multidrugresistant CEM/ADR5000 cells than in parental CCRFCEM cells, compounds $\mathbf{A}$ and $\mathbf{B}$, as well as the semisynthetic compound $\mathbf{3}$, showed minor cross-resistance in the otherwise highly drug-resistant CEM/ADR5000 cells. Regarding the structure-activity relationship, it clearly appeared that O-prenylation at position C4' of $\mathbf{B}$ to afford $\mathbf{3}$ considerably reduced the cytotoxic activity. In addition to the O-prenylation, acetylation at C-2' of $\mathbf{3}$ to afford $\mathbf{4}$ or at $\mathrm{C} 5$ of $\mathbf{1}$ to yield 2, further reduced the antiproliferative activity. These data clearly suggest that semi-synthesis

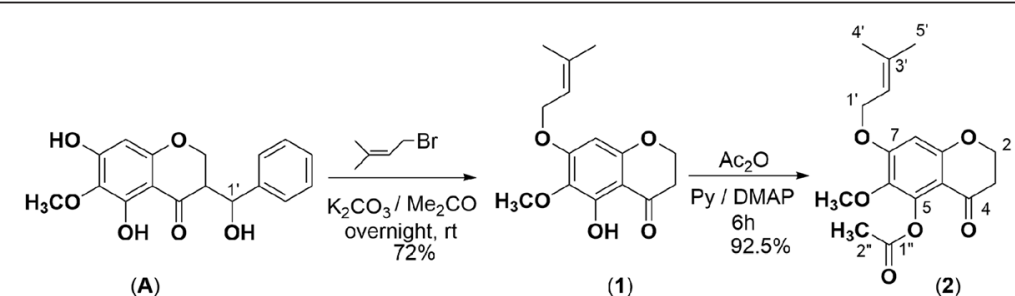

Fig. 1 Semi-synthesis of compounds $\mathbf{1}$ and $\mathbf{2}$ from 5,7-dihydroxy-3-(1'-hydroxy-1'-phenyl-methyl)-6-methoxy-chroman-4-one (A) 
Table 1 Comparative NMR data of 1-Methylhydantoin

\begin{tabular}{llll}
\hline Position & \multicolumn{2}{c}{ Compound C 1-Methylhydantoin } & Reference data (7) \\
\cline { 2 - 4 } & $1 \mathrm{H}(\mathrm{MeoD})(75 \mathrm{MHz})$ & $13 \mathrm{C}(\mathrm{MeoD})(75 \mathrm{MHz})$ & $1 \mathrm{H}$ DMSO (100 MHz) \\
\hline$-\mathrm{CH} 3$ & $2.91(\mathrm{~s})$ & 53.9 & $2.80(\mathrm{~s})$ \\
$-\mathrm{CH} 2$ & $3.95(\mathrm{~s})$ & 29.2 & $3.86(\mathrm{~s})$ \\
$-\mathrm{NH}-$ & - & - & $10(\mathrm{br} \mathrm{s})$ \\
$\mathrm{C}_{2}=\mathrm{O}$ & - & 159.9 & - \\
$\mathrm{C}_{4}=\mathrm{O}$ & - & 173.8 & - \\
\hline
\end{tabular}

involving O-prenylation and acetylation of chalcones or chromones should be avoided in the search for potential anticancer drugs. Usually it has been found that Cprenylation of the flavonoid nucleus increases the cytotoxic activity [9]. Moreover, as an additional benefit, prenylated flavonoids are relatively non-toxic to non-cancer cells [9]. In our case, O-prenylation was accompanied by a decrease in bioactivity, indicating the importance of free phenolic groups. This conclusion is further supported by the observation that, after prenylation, acetylation of the remaining free phenolic groups further reduced the cytotoxicity.

\section{Conclusions}

The objective of this study was to modify the structures of antitumor compounds $\mathbf{A}$ and $\mathbf{B}$ by O-prenylation and acetylation and to evaluate the structure-activity relationship (SAR). The results clearly suggest that O-prenylation and acetylation of chalcones, chromanones and possibly other flavonoids should be avoided in the search for potential anticancer drugs.

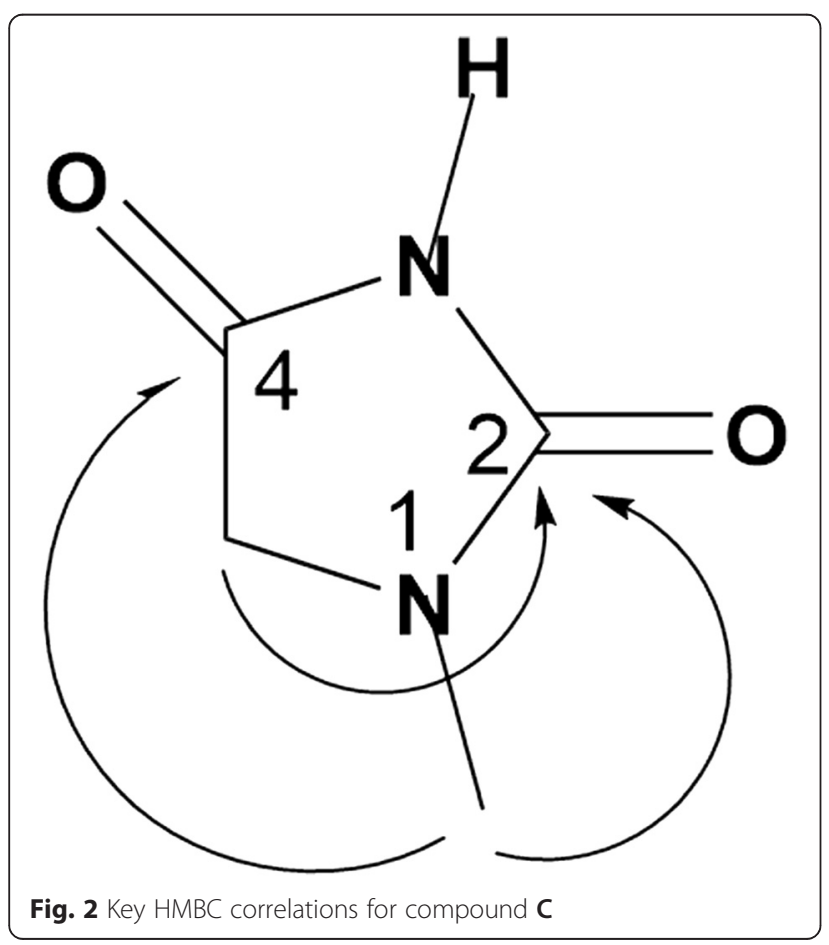

\section{Methods}

The starting materials, 5,7-dihydroxy-3-(1'-hydroxy-1' phenyl-methyl)-6-methoxy-chroman-4-one (A) and 2',4'dihydroxy-3',6'-dimethoxychalcone (B), were isolated from the leaves of Polygonum limbatum as previously reported [3, 4]. The purity of semi-synthetic compounds 1, 2, 3, and 4 was determined by analytical HPLC and was found to be $>98 \%$. Melting points were determined on a Büchi SMP-20 melting point apparatus and with a Reichert microscope and are uncorrected. IR spectra were recorded on a SHIMADZU FTIR-8400S spectrophotometer. EI-MS (ionization voltage $70 \mathrm{eV}$ ) and ESI-MS spectra were recorded on a Finnigan MAT double focusing spectrometer Model 8230. ${ }^{1} \mathrm{H}$ NMR (300 MHz) and ${ }^{13} \mathrm{C}$ NMR (75 MHz) spectra were recorded in $\mathrm{CDCl}_{3}, \mathrm{DMSO}-d_{6}$ and MeOD using a Varian Mercury Plus NMR spectrometer $(7.05 \mathrm{~T})$ and TMS as an internal reference. Silica gel 60 (70-230 mesh ASTM; Merck; Darmstadt, Germany) was used for column chromatography with step- gradients of $n$-hexane-EtOAc and EtOAc-MeOH as eluents. Precoated silica gel plates (Merck, Kieselgel $60 \mathrm{~F}_{254}$ ) were used for TLC. Spots were visualized at 254 and $365 \mathrm{~nm}$, and by spraying with $50 \% \mathrm{H}_{2} \mathrm{SO}_{4}$ followed by heating at $100{ }^{\circ} \mathrm{C}$.

\section{Plant material}

Polygonum limbatum Meisn. was collected in Balatchi village in the Metap swampy area, near the city of Mbouda, Western Region of Cameroon in March 2010. The plant was identified at the Cameroon National Herbarium, Yaoundé, where a voucher specimen was deposited under the reference number 38852/HNC.

\section{Extraction and isolation}

We previously reported the isolation of 5,7-dihydroxy-3(1'-hydroxy-1' -phenyl-methyl)-6-methoxy-chroman-4-one (A) and 2',4'-dihydroxy-3',6'-dimethoxychalcone (B) from the crude extract of $P$. limbatum [3]. A re-isolation of the compounds was performed following our previously described procedure [3] with some modifications that allowed the isolation of other flavonoids, 1-methylhydantoin (C) and terpenoids. A portion of the $\mathrm{MeOH}$ extract (7 g) was submitted to separation by column chromatography and HPLC, affording compounds $\mathbf{C}, \mathbf{D}$ and $\mathbf{E}$ (Fig. 5). 


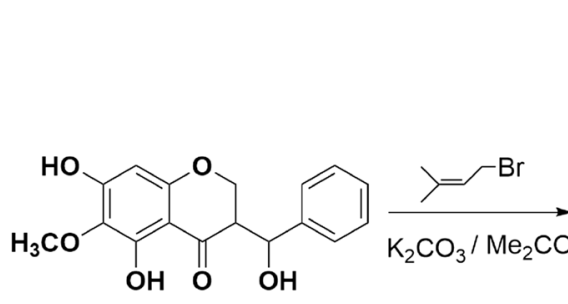

(A)<smiles>COc1c(OCC=C(C)C)cc2c(c1O)C(=O)C(CC(O)(c1ccccc1)c1ccccc1)CO2</smiles>

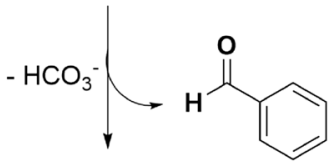<smiles>COc1c(OCC=C(C)C)cc2c(c1O)C(=O)C[C@H](C(=O)[O-])C2</smiles>

(1)<smiles>COc1c(OCC=C(C)C)cc2c(c1O)C([O-])=CCO2</smiles>

Fig. 3 Proposed retro-aldol-like reaction for the genesis of compound $\mathbf{1}$ from $\mathbf{A}[12]$

\section{Semisynthetic compounds}

O-Prenylation of 5,7-dihydroxy-3-(1'-hydroxy-1'-phenylmethyl)-6-methoxy-chroman-4-one to metapchromone (1) Compound A (10 mg, $\left.30 \times 10^{-3} \mathrm{mmol}\right)$ was dissolved in $2 \mathrm{~mL}$ of acetone $(0.1 \mathrm{M})$, and $1.7 \mathrm{~mL}$ of prenyl bromide and $\mathrm{K}_{2} \mathrm{CO}_{3}$ (3.4 mg, $38.6 \times 10^{-3} \mathrm{mmol}$ ) were added successively. The mixture was stirred overnight at room temperature (Fig. 1). Distilled water $(10 \mathrm{~mL})$ was added to the mixture, which was stirred for $25 \mathrm{~min}$. Extraction with $\mathrm{CH}_{2} \mathrm{Cl}_{2}$ and chromatographic purification on a silica gel column with mixtures of $n$-hexane-EtOAc gave a new derivative, 5-hydroxy-6-methoxy-7-O-(3'methylbut-2' -enyl)chroman-4-one (1) (7.2 mg, $72 \%)$, trivially named metapchromone.

\section{5-Hydroxy-6-methoxy-7-O-(3' -methylbut-2' -enyl)-} chroman-4-one (1) Yellow powder; mp $75-77^{\circ} \mathrm{C}$; IR $(\mathrm{KBr}): v_{\max }=2933,1647,1571,1449,1289,1105,808 \mathrm{~cm}^{-1}$;

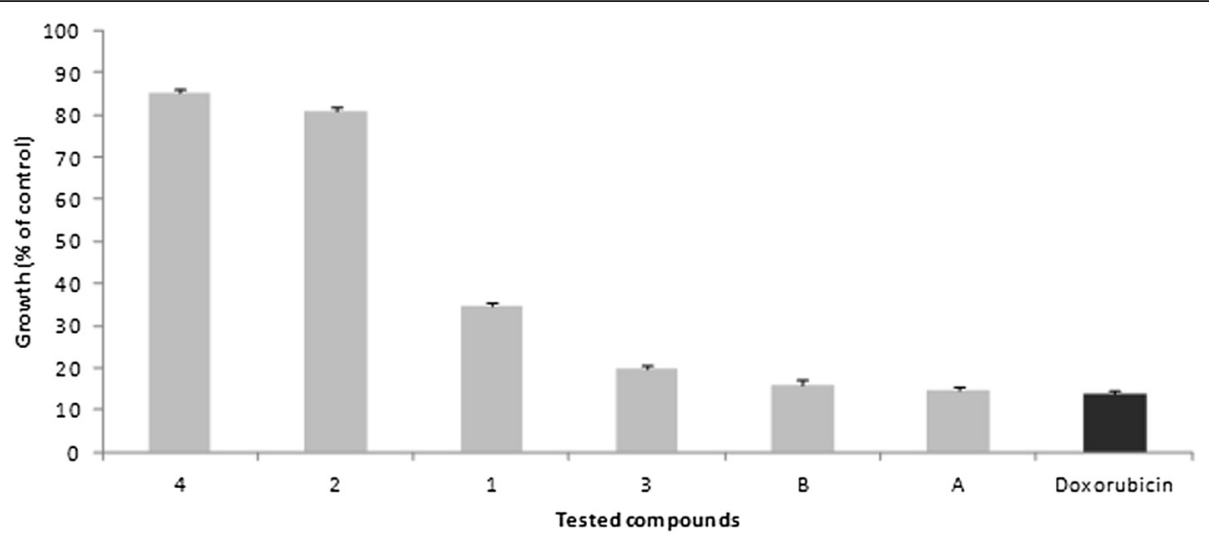

Fig. 4 Cytotoxicity activity of compounds on leukaemia CCRF-CEM cells at $125 \mu \mathrm{M}$.5,7-dihydroxy-3-(1'-hydroxy-1'-phenyl-methyl)-6-methoxychroman-4-one (A), 2',4'-dihydroxy-3',6'-dimethoxychalcone (B); 5-hydroxy-6-methoxy-7-0-(3',3'-dimethylprop-2'-enyl)chroman-4-one (1), 5-acetyl6-methoxy-7-O-(3',3'-dimethylprop-2'-enyl)chroman-4-one (2), 2'-hydroxy-3',6'-dimethoxy-4'-O-(3",3"-dimethylprop-2"-enyl)chalcone (3), 2'-acetyl3',6'-dimethoxy-4'-0-(3",3"-dimethylprop-2"-enyl)chalcone (4). Doxorubicin was used as a positive control 
Table 2 Cytotoxicity of compounds A, B, 1-4 towards sensitive and drug-resistant cancer cell lines and normal cells, as determined by the resazurin assay

\begin{tabular}{|c|c|c|c|c|c|c|c|}
\hline \multirow[t]{3}{*}{ Cell lines } & \multicolumn{7}{|c|}{ Compounds $(\mu \mathrm{M})$ and degrees of resistance (in brackets) } \\
\hline & \multicolumn{6}{|c|}{ Flavonoid derivatives } & \multirow[t]{2}{*}{ Doxorubicin } \\
\hline & $\bar{A}$ & $\mathrm{~B}^{\#}$ & 1 & 2 & 3 & 4 & \\
\hline CCRF-CEM & $7.85 \pm 0.82$ & $10.67 \pm 0.73$ & $(-)$ & $(-)$ & $18.07 \pm 2.04$ & $(-)$ & $0.20 \pm 0.06$ \\
\hline CEM/ADR5000 & $15.03 \pm 1.02$ & $18.60 \pm 2.60$ & $(-)$ & $(-)$ & $19.70 \pm 1.86$ & $(-)$ & $195.12 \pm 14.30$ \\
\hline Degree of resistance ${ }^{a}$ & $(1.91)$ & $(1.74)$ & & & $(1.09)$ & & $(975.60)$ \\
\hline
\end{tabular}

${ }^{a}$ The degree of resistance was determined as the ratio of $\mathrm{IC}_{50}$ value of the resistant/IC ${ }_{50}$ sensitive cell line; 5,7-dihydroxy-3-(1'-hydroxy-1'-phenyl-methyl)-6methoxy-chroman-4-one (A), 2',4'-dihydroxy-3',6'-dimethoxychalcone (B); 5-hydroxy-6-methoxy-7-O-(3',3'-dimethylprop-2'-enyl)chroman-4-one (1), 5-acetyl-6-

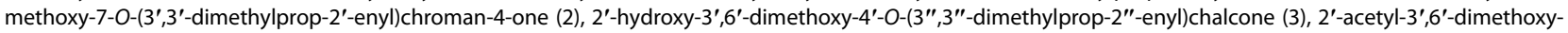
$4^{\prime}-0-\left(3^{\prime \prime}, 3^{\prime \prime}\right.$-dimethylprop-2"-enyl)chalcone (4).(-):>125 $\mu \mathrm{M}$; \# data previously reported [4]

ESIMS: $m / z 579.30[2 \mathrm{M}+\mathrm{Na}]^{+} ; 301.09[\mathrm{M}+\mathrm{Na}]^{+} ; 233.00 .{ }^{1} \mathrm{H}$ NMR $\left(300 \mathrm{MHz}, \mathrm{CDCl}_{3}\right)$ and ${ }^{13} \mathrm{C} \mathrm{NMR}\left(75 \mathrm{MHz}, \mathrm{CDCl}_{3}\right)$ : see Table 3.

\section{Acetylation of 5-hydroxy-6-methoxy-7-0-(3'-methylbut-2'- enyl)chroman-4-one (1) to sargisin (2)}

Compound $1\left(4 \mathrm{mg}, 10 \times 10^{-3} \mathrm{mmol}\right)$ was dissolved in pyridine $(0.5 \mathrm{~mL}) ; \mathrm{Ac}_{2} \mathrm{O}(8 \mathrm{~mL})$ and 4-dimethylaminopyridine (DMAP) (1 mg) were added, and the mixture was stirred at room temperature for $24 \mathrm{~h} . \mathrm{H}_{2} \mathrm{O}(8 \mathrm{~mL})$ was then added to the mixture, which was stirred for 30 min (Fig. 1). Extraction with $\mathrm{CH}_{2} \mathrm{Cl}_{2}$ and chromatographic purification on a Sephadex LH-20 gel column with $\mathrm{CH}_{2} \mathrm{Cl}_{2} / \mathrm{MeOH}$ (6:4) as isocratic eluent gave a new derivative, 5-acetoxy-6-methoxy-7-O-(3'-methylbut-2' -enyl)chroman-4-one (2) (3.7 mg, $92.5 \%)$, which was crystallized from $n$-hexane-EtOAc (7:3) and trivially named sargisin.

5- Acetoxy-6-methoxy-7-O- (3' - methylbut- 2' - enyl)chroman-4-one (2) Brownish powder, mp 87-89 ${ }^{\circ} \mathrm{C}$, ESIMS: $m / z 663.06[2 \mathrm{M}+\mathrm{Na}]^{+}, 603.33[2 \mathrm{M}-\mathrm{AcOH}+\mathrm{Na}]^{+}$, $543.40[2 \mathrm{M}-2 \mathrm{AcOH}+\mathrm{Na}]^{+}$, 343.34 $\left([\mathrm{M}+\mathrm{Na}]^{+} ;{ }^{1} \mathrm{H} \mathrm{NMR}\right.$ $\left(300 \mathrm{MHz}, \mathrm{CDCl}_{3}\right)$ and ${ }^{13} \mathrm{C}$ NMR $\left(75 \mathrm{MHz}, \mathrm{CDCl}_{3}\right)$ see Table 3.
O-Prenylation of 2',4'-dihydroxy-3', 6'-dimethoxychalcone (B) to limbachalcone $A$ (3)

Compound B $\left(10 \mathrm{mg}, 30 \times 10^{-3} \mathrm{mmol}\right)$ was dissolved in $3 \mathrm{~mL}$ of acetone $(0.1 \mathrm{M})$; prenyl bromide $(2 \mathrm{~mL})$ and $\mathrm{K}_{2} \mathrm{CO}_{3}$ (3 mg) were added successively. The mixture was heated at $40{ }^{\circ} \mathrm{C}$ for $3 \mathrm{~h}$ (Fig. 6). Distilled $\mathrm{H}_{2} \mathrm{O}(10 \mathrm{~mL})$ was then added to the mixture, which was stirred for $40 \mathrm{~min}$. Extraction with $\mathrm{CH}_{2} \mathrm{Cl}_{2}(3 \times 10 \mathrm{~mL})$, dryingover $\mathrm{Na}_{2} \mathrm{SO}_{4}$, and chromatographic purification on a silica gel column with mixtures of $n$-hexane-EtOAc yielded, after crystallization, 2 '-hydroxy3',6'-dimethoxy-4'-O-(3"'-methylbut-2"'-enyl)chalcone (3) (8.4 mg, 84 \%), trivially named limbachalcone A.

2'-Hydroxy-3',6'-dimethoxy-4'-O-(3"'-methylbut-2" enyl)chalcone (3) Yellowish powder; $\mathrm{mp} 98-100{ }^{\circ} \mathrm{C}$; IR $(\mathrm{KBr}): v_{\max }=2931,1629,1560,1334,1119,792 \mathrm{~cm}^{-1} ;{ }^{1} \mathrm{H}$ $\left(300 \mathrm{MHz}, \mathrm{CDCl}_{3}\right)$ and ${ }^{13} \mathrm{C} \mathrm{NMR}\left(75 \mathrm{MHz}, \mathrm{CDCl}_{3}\right)$; ESIMS: $m / z 1126.92[3 \mathrm{M}+\mathrm{Na}]^{+}, 759.83[2 \mathrm{M}+\mathrm{Na}]^{+}, 391.25$ $[\mathrm{M}+\mathrm{Na}]^{+}$.

Acetylation of 2'-hydroxy-3',6'-dimethoxy-4'-O(3"-methylbut-2"-enyl)chalcone to tsedengchromone (4)

Compound 1 ( $\left.3.2 \mathrm{mg}, 10 \times 10^{-3} \mathrm{mmol}\right)$ was dissolved in pyridine $(0.4 \mathrm{~mL}) ; \mathrm{Ac}_{2} \mathrm{O}(5 \mathrm{~mL})$ and DMAP $(1 \mathrm{mg})$<smiles>COc1cc2c(c(OC)c1O)C(=O)CCO2</smiles><smiles>CC(=O)Oc1c2cc(OCC=C(C)C)c(O)c1OCC2</smiles><smiles>COc1cc(OCC(C)C)c(O)c(OC)c1OCC(=O)c1ccccc1</smiles>

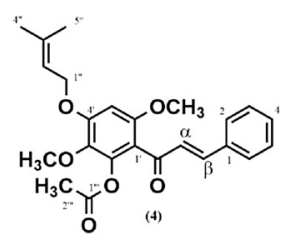<smiles>COc1c(O)cc2c(c1O)C(=O)C([C@H](O)c1ccccc1)CO2</smiles><smiles>CN1CC(=O)NC1=O</smiles>

(A)

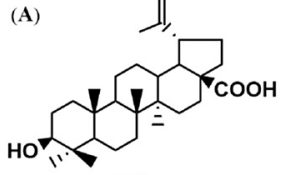

(D)<smiles>COc1cc(O)c(O)c(C(=O)C=Cc2ccccc2)c1O</smiles>

(B)

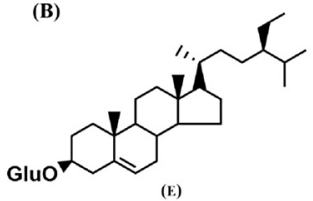

Fig. 5 Chemical structures of compounds 
Table $3{ }^{1} \mathrm{H}$ NMR (300 MHz) and/or ${ }^{13} \mathrm{C}$ NMR (75 MHz) data for compounds 1, 2, 3, 4 in $\mathrm{CDCl}_{3}[\delta(\mathrm{ppm})$, J(Hz)]

\begin{tabular}{|c|c|c|c|c|c|c|c|}
\hline \multirow[b]{2}{*}{ Position } & \multicolumn{2}{|l|}{1} & \multicolumn{2}{|l|}{2} & \multicolumn{2}{|l|}{3} & \multirow{2}{*}{$\begin{array}{c}4 \\
\delta_{H}\end{array}$} \\
\hline & $\overline{\delta_{H}}$ & $\delta_{C}$ & $\overline{\delta_{H}}$ & $\delta_{C}$ & $\overline{\delta_{H}}$ & $\delta_{C}$ & \\
\hline 1 & - & - & - & - & - & 138.3 & - \\
\hline 2 & $4.46(\mathrm{dd}, 6.54,12.86)$ & 65.7 & $4.46(\mathrm{dd}, 6.54,12.86)$ & 65.8 & $7.41(\mathrm{~m})$ & 127.4 & $7.41(\mathrm{~m})$ \\
\hline 3 & $2.78(\mathrm{dd}, 6.55,12.87)$ & 36.4 & $2.68(\mathrm{dd}, 5.13,14.07)$ & 38.1 & $7.45(\mathrm{~m})$ & 128.2 & $7.45(\mathrm{~m})$ \\
\hline 4 & - & 196.1 & - & 188.7 & $7.43(\mathrm{~m})$ & 128.7 & $7.43(\mathrm{~m})$ \\
\hline $4 a$ & - & 103.3 & - & 107.7 & & - & \\
\hline 5 & - & - & - & 155.1 & $7.45(\mathrm{~m})$ & 128.5 & $7.45(\mathrm{~m})$ \\
\hline $5-\mathrm{OH}$ & $11.91(\mathrm{~s})$ & 155.1 & - & - & & - & \\
\hline 6 & - & 128.9 & - & 128.9 & $7.42(\mathrm{~m})$ & 127.4 & $7.42(\mathrm{~m})$ \\
\hline $6-\mathrm{OCH}_{3}$ & $3.83(\mathrm{~s})$ & 60.6 & $377(s)$ & 61.1 & - & - & - \\
\hline 7 & - & 160.1 & - & 159.5 & - & - & - \\
\hline 8 & $6.08(\mathrm{~s})$ & 92.2 & $6.38(\mathrm{~s})$ & 99.1 & - & - & - \\
\hline $8 a$ & - & 158.6 & - & 158.5 & - & - & - \\
\hline $1^{\prime}$ & $4.61(\mathrm{~d}, 6.63)$ & 66.6 & $4.61(\mathrm{~d}, 6.63)$ & 66.9 & - & 107.2 & - \\
\hline $2^{\prime}$ & $5.48(\mathrm{brs})$ & 118.7 & 5.50 (brs) & 118.3 & - & 158.2 & - \\
\hline $2^{\prime}-\mathrm{OH}$ & - & - & - & & 13.93 & - & - \\
\hline $3^{\prime}$ & - & 138.6 & - & 139.0 & - & 130.0 & - \\
\hline $3^{\prime}-\mathrm{OCH}_{3}$ & - & - & - & & 3.85 & 55.8 & $3.79(\mathrm{~s})$ \\
\hline $4^{\prime}$ & $1.81(\mathrm{~s})$ & 25.6 & $1.83(\mathrm{~s})$ & 25.6 & - & 157.9 & - \\
\hline $5^{\prime}$ & $1.76(\mathrm{~s})$ & 18.1 & $1.77(\mathrm{~s})$ & 18.2 & 6.04 & 88.5 & $6.41(\mathrm{~s})$ \\
\hline $6^{\prime}$ & - & - & - & - & - & 159.4 & - \\
\hline $6^{\prime}-\mathrm{OCH}_{3}$ & - & - & - & - & 3.93 & 60.5 & $3.79(\mathrm{~s})$ \\
\hline $1 "$ & - & - & - & 169.3 & $4.71(\mathrm{~d}, 6.57)$ & 65.8 & $4.65(d, 6.52)$ \\
\hline $2^{\prime \prime}$ & - & - & $2.10(\mathrm{~s})$ & 20.8 & 5.52 (brs) & 119.2 & 5.52 (brs) \\
\hline $3 "$ & - & - & - & - & - & 138.3 & - \\
\hline $4 "$ & - & - & - & - & $1.83(\mathrm{~s})$ & 25.7 & $1.82(\mathrm{~s})$ \\
\hline $5^{\prime \prime}$ & - & - & - & - & $1.62(s)$ & 18.2 & $1.78(\mathrm{~s})$ \\
\hline$a$ & - & - & - & - & $7.81(\mathrm{~d}, 15.65)$ & 127.4 & $7.01(d, 16.06)$ \\
\hline$\beta$ & - & - & - & - & $7.90(d, 15.65)$ & 142.4 & $7.53(\mathrm{~d}, 8.49)$ \\
\hline$C=O$ & - & - & - & - & 13.93(s) & 193.0 & \\
\hline
\end{tabular}

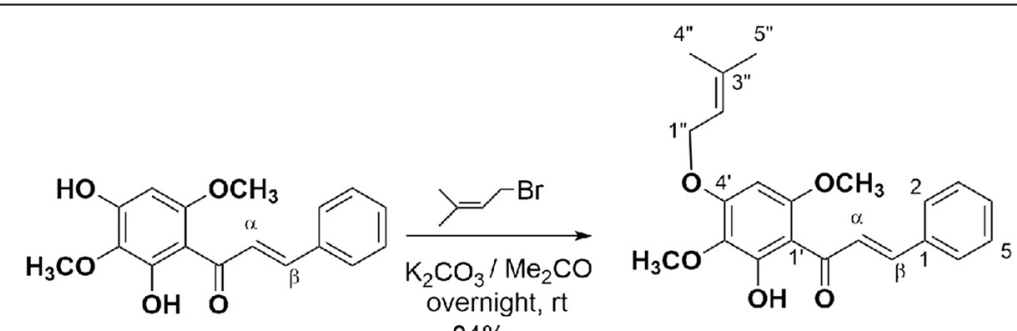

(B)

(3)

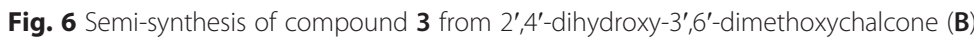


were added, and the mixture was stirred at room temperature for $24 \mathrm{~h}$ (Fig. 7). Distilled $\mathrm{H}_{2} \mathrm{O}(5 \mathrm{~mL})$ was then added to the mixture, which was stirred for 30 min. Extraction with $\mathrm{CH}_{2} \mathrm{Cl}_{2}$ and chromatographic purification on a Sephadex LH-20 gel column with $\mathrm{CH}_{2} \mathrm{Cl}_{2} / \mathrm{MeOH}$ (1:1) as isocratic eluent, yielded 2'acetoxy-3',6' -dimethoxy-4' -O-(3"'-methylbut-2"-enyl)chalcone (4) (2.8 mg, $87.5 \%$ ), which was crystallized from $n$-hexane-EtOAc $(6: 4)$ and trivially named tsedengchromone.

2' -Acetoxy-3',6'-dimethoxy-4' -O-[3"'-methylbut-2" enyl]chalcone (4) Brownish powder; $\mathrm{mp} 102-104{ }^{\circ} \mathrm{C}$; ESIMS: $m / z \quad 843.13[2 \mathrm{M}+\mathrm{Na}]^{+}, 433.42[\mathrm{M}+\mathrm{Na}]^{+} ;{ }^{1} \mathrm{H}$ NMR $\left(75 \mathrm{MHz}, \mathrm{CDCl}_{3}\right)$ see Table 3.

\section{1-Methylhydantoin (3-methyl-2,4-imidazolidine-} dione) (C) Brownish powder; mp $155-157^{\circ} \mathrm{C},{ }^{1} \mathrm{H}$ NMR $\left(75 \mathrm{MHz}, \mathrm{MeOH}-\mathrm{d}_{4}\right) ; \delta=3.95\left(3 \mathrm{H}, \mathrm{s}, \mathrm{CH}_{3}\right) ; 2.90$ $\left(2 \mathrm{H}, \mathrm{s}, \mathrm{CH}_{2}\right) ;{ }^{13} \mathrm{C}$ NMR $\left(75 \mathrm{MHz}, \mathrm{MeOH}-\mathrm{d}_{4}\right)$; see Table 2; EIMS $m / z$ (rel. int.): $114\left(\mathrm{M}^{+}, 35\right), 86$ (6), 42 (72).

\section{Cytotoxicity assay}

The resazurin reduction assay [10] was performed to assess the cytotoxicity of compounds and doxorubicin was used as a control drug towards the parental, drug-sensitive CCRF-CEM leukaemia cell line and its multidrug-resistant, P-glycoprotein-over-expressing subline, CEM/ADR5000. The assay is based on the reduction of the indicator dye, resazurin, to the highly fluorescent resorufin by viable cells. Non-viable cells rapidly lose their metabolic capacity to reduce resazurin and, thus, do not produce fluorescent signals anymore. Briefly, aliquots of $2 \times 10^{4}$ cells per well were seeded in 96-well-plates in a total volume of $100 \mu \mathrm{L}$. The studied compound was immediately added at varying concentrations to an additional $100 \mu \mathrm{L}$ of culture medium to obtain a total volume of $200 \mu \mathrm{L} /$ well. After $72 \mathrm{~h}$, resazurin (Sigma-Aldrich, Schnelldorf, Germany) $(20 \mu \mathrm{L}, 0.01 \% \mathrm{w} / \mathrm{v})$ in distilled $\mathrm{H}_{2} \mathrm{O}$ was added to each well and the plates were incubated at $37^{\circ} \mathrm{C}$ for $4 \mathrm{~h}$. Fluorescence was measured on an Infinite M2000 ProTM plate reader (Tecan, Crailsheim, Germany) using an excitation wavelength of $544 \mathrm{~nm}$ and an emission wavelength of $590 \mathrm{~nm}$. A preliminary assay was done with all samples on leukaemia CCRF-CEM cells at $125 \mu \mathrm{M}$. Each assay was done at least twice with six replicates each. The viability was evaluated by comparison with untreated cells. $\mathrm{IC}_{50}$ values represent the compound concentrations required to inhibit $50 \%$ of cell proliferation and were calculated from a calibration curve by linear regression with the aid of Microsoft Excel [11].

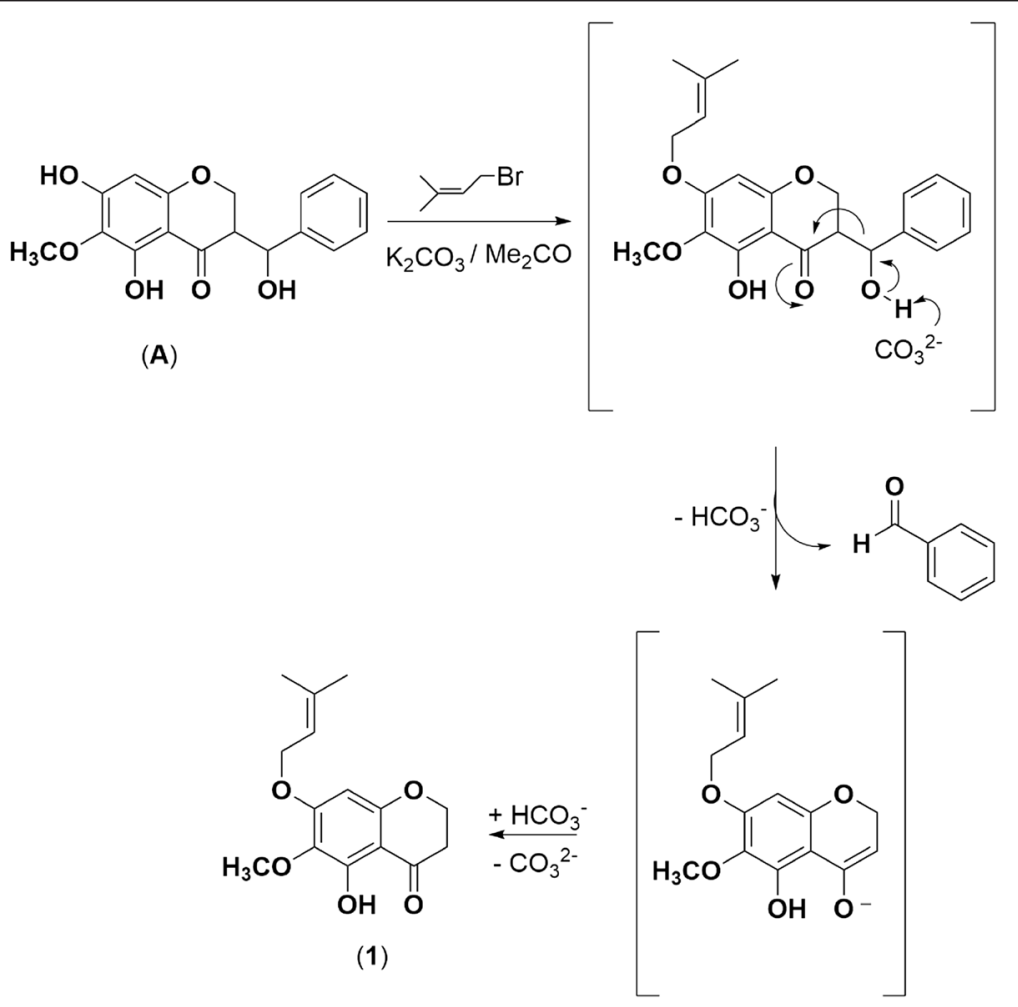

Fig. 7 Semi-synthesis of compound $\mathbf{4}$ from 2'-hydroxy-3',6'-dimethoxy-4'-O-(3"--methylbut-2"-enyl)chalcone (3) 


\section{Competing interests}

The authors declare that they have no competing interests.

\section{Authors' contributions}

AHLN, DG and VK performed the study; AHLN, HKW and PT contributed to the isolation and/or identification of compounds. $L M, A L$ and DV analysed the sample. AHLN drafted the manuscript. PT, HKW, OLF and TE designed the experiments; GV and OLF supervised the work, provided the facilities for the study, read and corrected the manuscript. All authors checked and validated the draft. All authors read and approved the final manuscript.

\section{Acknowledgements}

AHLN is grateful to the TWAS Fellowship for Research and Advanced Training and to CNPq for a 1-year training fellowship at the Centro de AnálisesProteômicas e Bioquímicas, Pós-Graduaçãoem Ciências Genômicas e Biotecnologia, Universidade Católica de Brasilia, Brasília, DF, Brazil. He also gratefully acknowledges the CICOPS scholarship through a travel grant at the University of Pavia. VK is very grateful to the Alexander von Humboldt foundation for an 18-month fellowship to visit the Department of Prof. Thomas Efferth (Johannes Gutenberg-University, Mainz, Germany) through the "Georg Foster Research Fellowship for Experienced Researcher" program for funding this work.

\section{Author details}

'Department of Chemistry, Faculty of Science, University of Dschang, Dschang, Cameroon. ${ }^{2}$ Centro de Analises Proteômicas e Bioquimicas, Pós-Graduação em Ciencias Genomicas e Biotecnologia, Universidade Catolica de Brasilia, Brasilia, DF, Brazil. ${ }^{3}$ Dipartimento di Chimica, Laboratorio di Chimica delle Sostanze Organiche Naturali e Centro di Etnobiofarmacia (CISTRE), Università degli Studi di Pavia, Via Taramelli, 12-27100 Pavia, Italy. ${ }^{4}$ Department of Pharmaceutical Biology, Institute of Pharmacy and Biochemistry, University of Mainz, Staudinger Weg 5, 55128 Mainz, Germany. Instituto de Química, Universidade de Brasília, Brasilia, DF, Brazil. ${ }^{6}$ Department of Biochemistry, Faculty of Science, University of Dschang, Dschang, Cameroon. ${ }^{7}$ S-Inova Biotech, Universidade Catolica Dom Bosco, Campo Grande, MS, Brazil.

Received: 25 December 2014 Accepted: 16 June 2015

Published online: 24 June 2015

\section{References}

1. Wang KJ, Zhang YJ, Yang CR. Antioxidant phenolic compounds from rhizomes of Polygonum paleaceum. J Ethnopharmacol. 2005;96:483-7.

2. Kiritikar KP, Basu BD. Indian medicinal plants, Allahabad, India. 2nd ed. 1999.

3. Dzoyem JP, Nkuete LAH, Kuete V, Tala MF, Wabo HK, Guru SK, et al. Cytotoxicity and antimicrobial activity of the methanol extract and compounds from Polygonum limbatum. Planta Med. 2012;78:787-92.

4. Kuete $V$, Nkuete LAH, Mbaveng TA, Wiench B, Wabo HK, Tane P, et al. Cytotoxicity and modes of action of $4^{\prime}$-hydroxy-2',6'-dimethoxychalcone and other flavonoids toward drug-sensitive and multidrug-resistant cancer cell lines. Phytomedicine. 2014;21:1651-7.

5. Tao SH, Wu FE. Studies on chemical constituents of Hypericum wightianum. J Asian Nat Prod Res. 2004;6:307-10.

6. De Andrade MR, Almeida EX, Conserva LM. Alkyl chromone and other compounds from Clusia nemorosa. Phytochemistry. 1998;47:1431-3.

7. Hans-Dieter D, Haireddin J, Kamp R, Kurz J, Wunsche C. 1-Methylhydantoin, ein unerwarteter Metabolit der nootropen Substanz Dupracetam. Arch Pharm (Weinheim). 1981;314:697-702.

8. Kuete V, Efferth T. Cameroonian medicinal plants: pharmacology and derived natural products. Front Pharmacol. 2010;1:123-7.

9. Šmejkal K. Cytotoxic potential of C-prenylated flavonoids. Phytochem Rev. 2014;13(1):245-75.

10. O'Brien J, Wilson I, Orton T, Pognan F. Investigation of the Alamar Blue (resazurin) fluorescent dye for the assessment of mammalian cell cytotoxicity. Eur J Biochem. 2000;267:5421-6.

11. Kuete V, Krusche B, Youns M, Voukeng I, Fankam AG, Tankeo S, et al. Cytotoxicity of some Cameroonian spices and selected medicinal plant extracts. J Ethnopharmacol. 2011;134:803-12.

12. Agrawal PK. Carbon-13 NMR of flavonoids. Elsevier. 1989;39:564-70. Netherlands.

\section{Publish with ChemistryCentral and every scientist can read your work free of charge \\ "Open access provides opportunities to our colleagues in other parts of the globe, by allowing anyone to view the content free of charge." W. Jeffery Hurst, The Hershey Company. \\ - available free of charge to the entire scientific community \\ - peer reviewed and published immediately upon acceptance \\ - cited in PubMed and archived on PubMed Central \\ - yours - you keep the copyright \\ Submit your manuscript here: \\ http://www.chemistrycentral.com/manuscript/}

